Notes on the Phytogeography and Flora of the Mountain Summit Plateaux of Tasmania Author(s): L. S. Gibbs

Source: Journal of Ecology, Vol. 8, No. 2 (Jun., 1920), pp. 89-117

Published by: British Ecological Society

Stable URL: http://www.jstor.org/stable/2255528

Accessed: 27-01-2016 06:16 UTC

Your use of the JSTOR archive indicates your acceptance of the Terms \& Conditions of Use, available at http://www.jstor.org/page/ info/about/policies/terms.jsp

JSTOR is a not-for-profit service that helps scholars, researchers, and students discover, use, and build upon a wide range of content in a trusted digital archive. We use information technology and tools to increase productivity and facilitate new forms of scholarship. For more information about JSTOR, please contact support@jstor.org.

Wiley and British Ecological Society are collaborating with JSTOR to digitize, preserve and extend access to Journal of Ecology. 


\section{NOTES ON THE PHYTOGEOGRAPHY AND FLORA OF THE MOUNTAIN SUMMIT PLATEAUX OF TASMANIA}

(continued from p. 17).

By L. S. GIBBS.

\section{CONTENTS.}

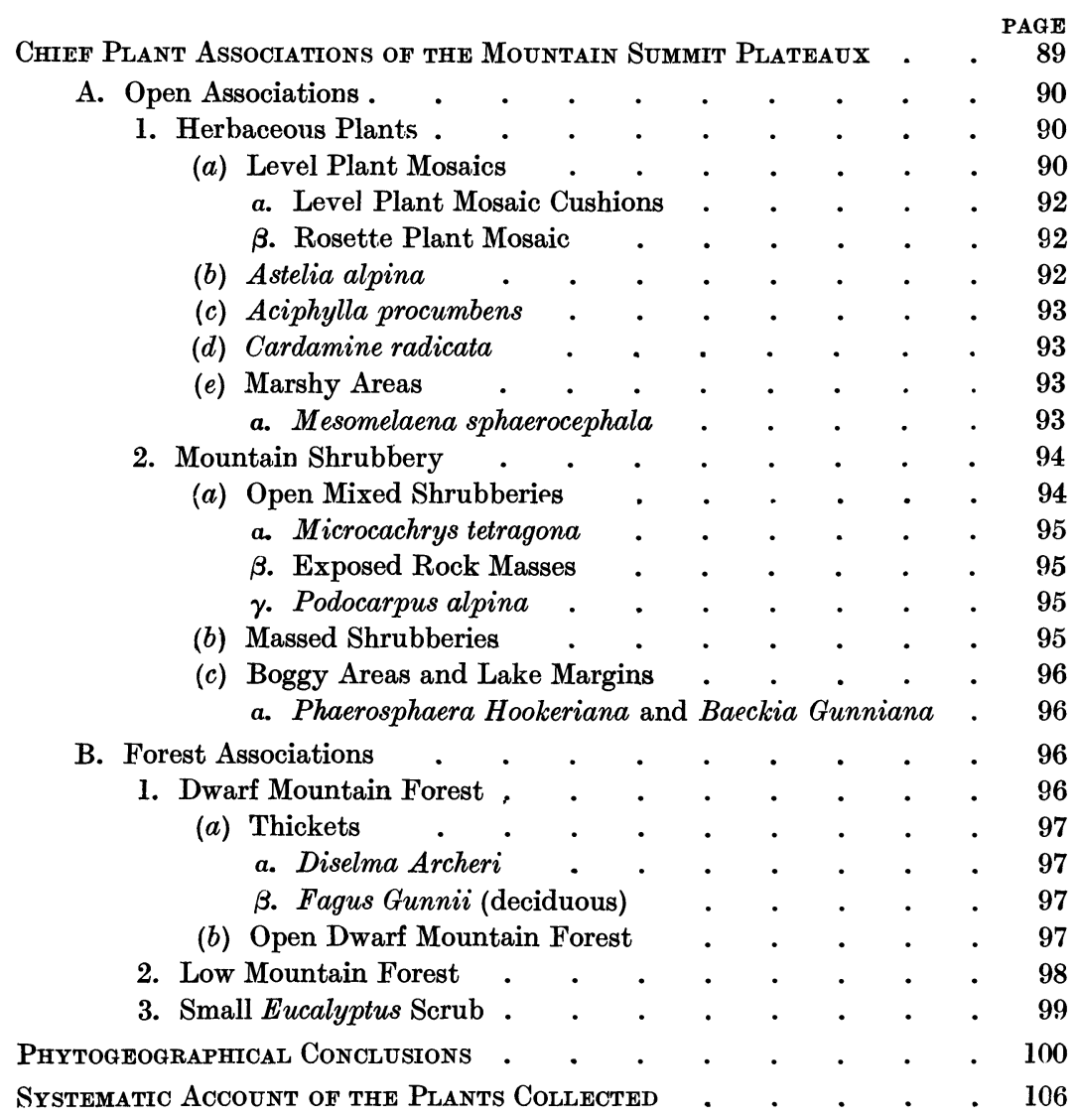

CHIEF PLANT ASSOCIATIONS OF THE MOUNTAIN SUMMIT PLATEAUX.

Only those plants in flower or otherwise determinable at the time of collection, given in every case in the systematic account, have been enumerated.

The vegetation of these areas is very homogeneous in character, relatively poor in species and determined as would be expected by the physiographical limitations.

Journ. of Ecology VIII 
The flowering season also varies on the different mountains according to latitude and season, and it may be due to this fact that certain endemic plants have been collected on certain mountains only, which are not generally accessible; such are * Cardamine radicata, so far limited to Mts Olympus, La Perouse and Humboldt; *Geum renifolium to Adamson's Peak and La Perouse; and *Aciphylla procumbens, to the two latter peaks and the Hartz Mountains; all very distinct plants, solitary representatives of their respective genera, which in the case of the two former are world-wide mountain types, while the latter is limited to the southern hemisphere.

The predominant flower colour is yellow to white, then pink to red. The same sequence also holds for Tierra del Fuego, where according to Skottsberg ${ }^{1}$, there are no bumble bees or bees, few butterflies, while smaller Lepidoptera are abundant and, with flies, are probably the chief agents in cross fertilisation.

In the mountain flora of New Zealand, white, merging to' yellow, is again predominant while red is barely represented, and Hilgendorf ${ }^{2}$ states that species of night-flying honeysuckers are probably about two-thirds in excess of the day-flying ones, which agrees with Skottsberg's results, and no doubt also holds for the austral-montane element in Tasmania as well.

Herbaceous plants, as already noticed, are more conspicuous by their absence than by their presence under prevailing austral-montane and subantarctic conditions. In the Tasmanian mountains, much more restricted than even in New Zealand, their limits can be defined, but the associations, other than that of the level plant mosaic, are so small that it is difficult to describe them in exact terms.

Following the natural sequence of development in the floral mountain covering, the chief plant associations are taken serially from the highest points downwards, as they are found at the present time.

\section{A. Open Associations.}

\section{Herbaceous Plants.}

(a) Level Plant Mosaics.

On the most exposed and highest levels where the snow rests all the winter, and remains till well into the summer months, melting imperceptibly so that no water remains on the ground, a mosaic of small moss-like plants is developed, of which the members, never encroaching on each other's limits, or exceeding a couple of inches above ground, spread with dispassionate evenness over the levelled surfaces of former rock masses for a few roods or even acres in extent. The different shades of foliage blend and contrast,

1 Carl Skottsberg. "Feuerländische Blüten." Wiss. Erg. Schwed. Südpol. Exp. 1901-1903, Bd. Iv. Lief. 2, p. 3.

2 F. W. Hilgendorf. "Notes from the Mountain Biological Station, Cass. No. 6.-The Insect-Iife." Trans. New Zealand Inst. 50, p. 138. 
strongly suggesting a mosaic pavement, but the flowers are inconspicuous, plane with the surface, the peduncles elongating about $10-15 \mathrm{~mm}$. in fruit.

This peculiar association includes Donatia novae-zelandiae, bright green, as common as on the S. New Zealand mountains, mottled with the silvergrey *Pterygopappus Lawrencii and the greenish-brown *Abrotanella forsterioides, all dotted with minute plantlets of pilose, grey-green Plantago Gunnii; with Oreobolus pumilio, *Mitrasacme Archeri, Pernettya tasmanica and Erigeron pappochromus often wedged tightly in between.

This even surface, quite hard to walk on, not yielding in the slightest degree to pressure, is apical in growth, the small exposed growing points tipping the successive growth of many years. These plants cannot therefore rightly be described as carpeting, the ultimate branches alone being moss-like in appearance but very rigid in fact.

Early stage. On the N.E. extremity of the summit-ridge of Mt Field W. this association was seen in its incipient and consequently restricted stage, having taken possession of all the level surface available, over which it spread as evenly as if laid down with a spirit level. Later stages. In older and larger associations, adequate conditions for lateral expansion being limited, the plants increase vertically, resulting in a billowing of the whole surface, described by Legge ${ }^{1}$ in 1886 on Ben Lomond as follows: "it spreads out like a green table beautifully patched or mapped out, so to speak, with pale greenish white tracts on the dark green ground of the larger portion of the plant, and rises up here and there into round, pudding like masses, reaching a diameter of two feet or more," while Gunn (Herb. Kew.) notes: "Acres of these plants occur on the highest parts of the Western Mts where the ground is wet... all forming one solid mass."

This stage stretches over the summit of Mt Read, with *Helichrysum pumilum and $* H$. Milligani associated, the latter limited to W. Coast summits: on Mt Humboldt; and on Mt Hartz, it covered a large area at the foot of the Pinnacle, with Prasophyllum fuscum var., about $1 \mathrm{dm}$. high, dotted over the billows, the only orchid collected on any of the summit plateaux visited.

The Level Plant Mosaic must have formed the chief plant covering on the huge high tableland that was Tasmania, taking possession of the surface gradually exposed as glacial conditions became modified. In this case, it replaces the bryophyte vegetation of boreal fell fields, where mosses like Grimmia hypnoides, of which the wide stretches are so conspicuous in Iceland, act as the first soil forming agents on barren, wind-swept rock.

The succession to the mosaic where limited, is no doubt that of the mountain shrubbery, for as the rock mass which supports it is etched away and breaks up, so the accumulated humus becomes wedged between the crannies, forming root holds for larger plants. Over larger areas where the mosaic association

1 w. v. Legge. "Highlands of Lake St Clair." Loc. cit. pp. 120-121. 
has billowed vertically to the limit of possible development it would incline to split apart, allowing water to accumulate, which, increasing in volume, must ultimately kill the plants at the roots, and peat bogs, like those at the head of Lake Fenton on Mt Field E., result. Certainly there is no other vegetative growth to account for such development under present conditions.

\section{$\alpha$. Level Plant Mosaic Cushions.}

On Mt Field E., near the foot of the summit cone of broken stones, an area of ground with running water was covered with isolated solid cushions over $.50 \mathrm{~m}$. high and about $.75 \mathrm{~m}$. in diameter of these same plants in identical association.

It is unusual to see many cushions of single plants of similar size, but for mixed plants to assume this form was new to me, and it seemed to be only explicable by the belief that these plants were forced to acquire the cushion habit instead of the usual mosaic on some physiological ground, possibly connected with the presence of standing or running water at their roots.

That a whole series of plants together should alternate their habit according to habitat proves that habit is not so much a hereditary acquisition as a response to the physiological necessities of actual environment.

\section{$\beta$. Rosette Plant Mosaic.}

Only seen in Tasmania on the rounded exposed cap of Moore's Pimple on Mt Read, which, just rising above the tree level, was covered with an even growth of rosette plants, of which Erigeron pappochromus and Helichrysum pumilum both in flower in October, formed the chief part. This type of plant mosaic was first noted in the Mt Cook district of the New Zealand Alps, and judged then to be typically austral-montane, as it recalled no similar association in the alpine regions of Europe or N. America.

There at $7000^{\prime}$ on the top of Mt Wakefield I saw some beautiful examples of this habit of growth. Lovely little dwarf Celmisias and still smaller Raoulias, with tufts of leaves of various shades of silver grey and green dotted with white star-like flowers, the several species, disclaiming all competition, each rigidly adhering to its allotted area in the general scheme. Lying well above the snow line and all shrubby growth, with the exception of some dwarf Veronicas, these plants were exposed for a very short time in the summer, under the same conditions of even evaporation which favours the development of the level plant mosaic of the Tasmanian mountain tablelands, but not observed on the rugged New Zealand Alps.

\section{(b) Astelia alpina.}

On the northern crest of the summit plateau of Mt Field E., large areas were covered with the silver leaved "Artichoke," Astelia alpina, especially in cup-shaped depressions where the snow persisted longest. On mossy cushions 
covering large boulders the tiny blue Wahlenbergia saxicola, previously only known from Mt Wellington, Herpolirion novae-zelandiae, Veronica nivea, were associated with the shrubs *Orites diversifolia and *O. acicularis, *Tetracarpaea, Bauera, *Trochocarpa thymifolia, semi-prostrate to erect, with red flowers and blue berries, *Richea acerosa and $* R$. scoparia, both with white flowers, $* R$. sprengelioides and *Olearia ledifolia.

\section{(c) *Aciphylla procumbens.}

Dominant on the broken rock summit of the Pinnacle, the highest point of the Hartz Mountains, this plant stretched in large patches across, or formed cushions where wedged between the rocks with *Raoulia Planchoni, also small cushions of Donatia novae-zelandiae.

\section{(d) *Cardamine radicata.}

Only seen, dotted in small shaded couloirs, on Mt Olympus at 4000', where ${ }^{*}$ Cardamine radicata with its creamy flowers, the little pink heads of * Dichosciadium ranunculaceum, very like some saxifrages in habit, both with rope-like roots, *Ourisia integrifolia, gleaming white, the flowers identical in appearance with some of the New Zealand species, Euphrasia Brownii var. alpina, a fine variety with large leaves and almost corymbose heads of large white flowers, veined with mauve, ${ }^{*}$ Raoulia Planchon $i$ with *Senecio pectinatus var. ochroleuca were associated.

\section{(e) Marshy Areas.}

By Lake Webster on marshy ground, through which various threads of the Broad River straggled, the muddy banks at the water's edge carried minute dark green tufts of *Juncella filamentosa, the light green *Centrolepis monogyna and tiny ${ }^{*} C$. muscoides, the yellow ${ }^{*}$ Campynema lineare, Drosera Arcturi, the almost invisible minute, red $D$. pygmaea, the larger $D$. peltata, * Scaevola Hookeri, densely carpeting with its pretty pink flowers, Utricularia monanthos, Liparophyllum Gunnii and Celmisia longifolia, all in flower in December.

a. Mesomelaena sphaerocephala.

Lake Webster, of which the level, $3000^{\prime}$, is lower than the summit plateau, is limited on the west by forest clad, steep slopes, while on the other side spread large areas of marshy ground, which carried patches, some recently burnt, of "Button-grass," which often covers large plains on the West Coast. Similar in habit and habitat to Carex paniculata, which in Cornwall may be seen $1.25-1.75 \mathrm{~m}$. high, or the New Zealand $C$. secta, the spreading heads of grass-like leaves just meet to form even clumps.

C. secta however is rarely seen in natural condition, as growing in damp places, on dry plains regularly burnt over for grazing purposes, the foliage 
has little chance of developing, so the blunt, brown stumps alone remain to suggest the highly imaginative title of "Niggerheads," a reiterative rote of New Zealand floral descriptions. Certainly during a six months' stay in that country $\mathrm{I}$ never saw it except in a shorn and brown condition. In Tasmania, as in Cornwall, this euphonious appellation of a secondary unnatural state is fortunately unknown, as in both cases, the heavy rainfall would inhibit any permanent effect of such disfigurement.

\section{Mountain Shrubbery.}

This, the dominant association of the more exposed portions of the plateau summits, shows a well developed undergrowth, where edaphic conditions are more favourable, to be reduced to scattered shrubs on recent broken rock masses - or it may form a dense shrubbery, as on some parts of the wind swept summit of Mt Wellington.

\section{(a) Open mixed Shrubberies.}

Seen at their best round Lake Fenton on Mt Field E., along the open sides of the lake, which in November were gay with colour, most of the shrubs being then in flower, the effect was chiefly white, toning to the yellow of * Richea sprengelioides, and pink through the abundant Bauera, Sprengelia incarnata, and the red of the distinct * Richea scoparia. The shrubs in this area included all those common to this association, of pronouncedly xerophytic habit, showing rigid branching, generally copiously spreading from the base, about 1-1.50 m. in height, with small acicular or revolute, coriaceous leaves, each branch terminated with little flowering racemes.

In comparison with European conditions, where so much of the beauty of the High Alps is due to the wide colour scope of a single species, no one plant predominates, and though each species is abundantly represented, there is no grouping of effect, but all are evenly distributed over a carpet of dwarf shrubs, or the ubiquitous Bauera which, spreading over the ground in a massed tangled growth, or rising to about $1 \mathrm{~m}$. or more, is a preponderating feature of this as well as of many lowland heath associations.

The colour of the foliage varies from the yellow of the very general * Orites acicularis (Yellowbush) which makes up what it lacks in foliage by prolific branching, through the bright yellow-green of *Richea sprengelioides, the grey-green Rosemary-like *Orites revoluta, *Olearia ledifolia or *O. pinifolia, to the deep green of *Tetracarpaea, *Olearia persoonioides, Epacris and Helichrysum spp. not in flower.

Undergrowth. Of the dwarf shrubs, *Exocarpus humifusa spreads over stones, *Rubus Gunnianus, with white flowers and ternate leaves growing between them, while Pernettya tasmanica and Pentachondra pumila spread thickly often for over $1 \mathrm{~m}$. amongst stones and over soil, or assume a more rounded cushion habit. Euphrasia Brownii with large mauve flowers was the 
only herbaceous plant seen. All round the lake the extreme edge was fringed. with *Phaerosphaera Hookeriana, *Baeckia Gunniana, Epacris petrophila and E. serpyllifolia, both the latter a mass of white flowers.

$$
\alpha . * \text { Microcachrys tetragona. }
$$

On the crest of the plateau of Mt Field W. this species was dominant in a very interesting form of mountain shrubbery where the *Microcachrys formed a dense green carpet spreading for yards round well isolated groups of *Diselma Archeri, Podocarpus alpina, Coprosma nitida, *Olearia pinifolia with some others, the ends of the long branches showing in December the pretty pink cones. On Mt Read, in juxtaposition with dwarf mixed forest, this association was also seen, the creeping Microcachrys being associated with Lycopodium scariosum and the pretty little white Oxalis magellanica. Here in October the Microcachrys showed only the old dry persistent cones.

\section{$\beta$. Exposed Rock Masses.}

Peculiarly adapted to the most arid and exposed conditions, these shrubs are dominant on the cones and ridges left by the rapidly weathering diabase, where, showing little variety in species, and naturally no undergrowth, they form the first vegetative growth amidst the wastes of rock. On the N.W. and W. aspect of Mt Field W. amongst the huge, endless stone fields, grew the usual Orites, Olearia and shrubby Helichrysums of this assaciation, below the still standing broken combs of diabase which form the extreme summit ridge. Along the actual arête denudation was too pronounced and too recent to allow of any vegetative growth.

Up the summit cone of Mt Field E., *Leptospermum rupestre, *Orites acicularis and $* O$. revoluta, $*$ Richea scoparia, $*$ Olearia ledifolia, etc., with shrubby Helichrysums again dotted the broken rocks, rooting far below, their heads spreading between them. On the north side of the Lake Fenton a ridge of broken rocks bore the fastigiate *Orites diversifolia about $2 \mathrm{~m}$. in height and the prolific flowered *Helichrysum Backhousii with Euphrasia Brownii var. alpina, wedged between in places.

\section{$\gamma$. Podocarpus alpina.}

This charming little prostrate conifer, with tender light green foliage and fruiting abundantly, was very marked, creeping or massed over the broken rocks of the Pinnacle as they slope down to the Great Lake, on the Hartz summit plateau, associated with *Leptospermum rupestre of somewhat similar habit.

\section{(b) Massed Shrubberies.}

On the summit plateau of Mt Wellington, which is much more weathered and exposed, the mixed shrubs formed quite a dense growth in parts, where the lovely silky white *Pimelea sericea with pink heads of flowers, *Orites 
diversifolia, the spreading ${ }^{*}$ Leptospermum rupestre and * Styphelia straminea and S. montana, * Richea sprengelioides, Coprosma nitida, *Olearia persoonioides, ${ }^{*}$ Helichrysum antennarium and ${ }^{*} H$. Backhousii, ${ }^{*}$ Exocarpus humifusa, Bauera, Pentachondra pumila with the herbaceous *Mitrasacme montana, Celmisia longifolia and Lycopodium laterale, were in flower in December.

(c) Boggy Areas and Lake Margins.

$\alpha$. * Phaerosphaera Hookeriana and Baeckia Gunniana.

The head of Lake Fenton is fed by a large peat deposit scored by various streams which cut off numerous tarns and small islands, the latter showing undercutting as in tidal estuaries, all outlined by *Phaerosphaera Hookeriana, the delightfully fragrant Baeckia Gunniana with masses of tiny pinkish white flowers, and Helichrysum baccharoides, whose dark green, erect aphyllous branches, when not in flower, suggest some cupressoid species.

Where the peat was exposed on the edge of the water the large single flowered Drosera Arcturi, whose red foliage was as general on the Tasmanian mountains as on those of New Zealand, *Mitrasacme Archeri in small green tufts, with white flowers, and *Ourisia integrifolia were found. These boggy areas stretched across to the northern end of the summit plateau.

* Phaerosphaera and Baeckia Gunniana, characteristic of the margins of most mountain lakes and damp ground, were associated with * Telopea truncata on Lake Webster, Mt Field W., also tall straight clumps of grey-green Leptospermum lanigerum, the vertical branches with wandlike apices, white with blossom, and Melaleuca squamea of similar habit, but with stiff, deep green squarrose foliage, tipped with soft pink, mauve, or yellow flowers.

\section{B. Forest Associations.}

\section{Dwarf Mountain Forest.}

This, the most interesting because it was probably the first type of forest association developed in Tasmania, was only seen on the West Coast, on the most exposed western crest of the summit plateau of Mt Read.

On clay soil this true dwarf forest type consisted of trees like *Phyllocladus aspleniifolius, *Athrotaxis selaginoides, and *A. laxifolia, Atherosperma, which grew crowded together and dwarfed to the approximately same height as the shrubs *Diselma, *Orites Milligani, *Fagus Gunnii, Drimys aromatica, *Telopea, *Tetracarpaea, * Richea pandanifolia, the latter limited to one erect head, all about $2 \mathrm{~m}$. in height, no one species preponderating, with no undergrowth. 
(a) Thickets.

$\alpha$. Diselma Archeri.

$\beta$. Fagus Gunnii (deciduous).

On the eastern stonefield slopes of the summit ridge of Mt Field W., which drop $1000^{\prime}$ to the plateau below, drainage areas were covered with * Diselma Archeri, succeeded by a dense impenetrable growth of the deciduous * Fagus Gunnii. In habit and height rather like our filberts, but with more numerous and erect branches and tiny little bright green leaves, this species, like the deciduous Fagus antarctica ${ }^{1}$ of Tierra del Fuego, which grows there above the level of the evergreen beeches, seems limited to the summit plateaux.

In other depressions of the same ridge, completely covering the piled up stones, pure thickets of the dark green, scraggy *Diselma clothed the slopes, $\pm 1.50 \mathrm{~m}$. high, last year's wood densely covered with the minute old $q$ cones.

Both these species are gregarious, but such pure stands, devoid of undergrowth, were not observed elsewhere.

\section{(b) Open Dwarf Mountain Forest.}

This charming form of mountain association was seen at its best on the summit plateau of Mt Field W. at 3500' All the usual species of the mixed forest, in much dwarfed form, about three m. high, spread singly or lightly grouped over the surface, forming open glades as in a natural arboretum, no doubt the result of shelter combined with shallow poor soil.

*Athrotaxis selaginoides, much contorted where exposed, but naturally symmetrical, with the tapering or cupressoid habit of most abietineous youth forms, light green foliage and dense branching habit, interspersed by the dense heads of *Richea pandanifolia, *Fagus Gunnii, the straight shoots of * Telopea truncata, crowned by the handsome red flowers, the red stemmed Drimys aromatica, with a few scattered *Eucalyptus coccifera spread above ground green with various dwarf shrubs or broken by grey boulders.

These clumps were separated by the smaller, always close clipped Coprosma nitida and * Olearia pinifolia, which my guide pointed out was due to the fact that they form the favourite feeding of Kangaroo and Wallaby, of which the tracks were seen all over the mountain. *Bellendena montana, Sprengelia incarnata, *Richea sprengelioides, ${ }^{*}$ Orites revoluta and $* O$. acicularis, scattered broad patches of $*$ Diselma, with clipped, dense foliage, here 1.25-2 m., rarely even $3 \mathrm{~m}$. high, the more graceful $*$ Phaerosphaera up to $1 \mathrm{~m}$., with irregular elongating branches, white flowered Epacris and shrubby Helichrysum spp. Undergrowth. The undergrowth consists of stretches of erect dark green Gleichenia dicarpa, bright green *Microcachrys tightly pressed to the ground, *Centrolepis monogyna in small tufts, patches of the silvery Astelia alpina,

1 Carl Skottsberg. Distribution of Vegetation in the colder South Hemisphere, Ymer, xxv 1905, p. 418. 
Drosera Arcturi, where damper, with *Mitrasacme Archeri, the creeping Pernettya tasmanica with its red berries everywhere and Pentachondra pumila equally abundant.

Fairy mats of the tiny * Raculia catipes, the little white everlasting flowers, rising like a net of stars just above their bed of silver leaves, *Helichrysum pumilum, here clothed in white tomentum, with white flowers, the large mauve Euphrasia Brownii and the yellow Senecio pectinatus var. pleiocephalus dotted open places between.

A series of shallow limpid lakes enhanced the beauty of this sylvan scene, and of the rocks exposed, huge boulders lay in the lakes and round the edges, the plants on them emerging from the embedding club moss, L. scariosum, which spread evenly over the surface, with *Phaerosphaera and the fragrant Baeckia Gunniana massed round their base.

Open dwarf forest, judging by the charred remains, had also been dominant on the plateau summit of Mt Hartz. One part, surrounding two small lakes, showed the same facies as that of the summit plateau of Mt Field W. *Eucryphia Billardieri in full flower, massed on the edge of streams, and by the beautiful Great Lake, *Athrotaxis cupressoides, in symmetrical tiers, with *Leptospermum lanigerum var. grandifolium, *Archeria serpyllifolia and * Styphelia straminea var. macrantha were collected. At Lake Hartz, another fine sheet of water, *Tetracarpaea tasmanica, *Helichrysum antennarium and *H. Backhousii were in flower, while by Lake Esperance *Eucalyptus vernicosa, a neat bushy shrub, was quite abundant.

Pentachondra pumila, the equally dwarf * Styphelia dealbata with *Senecio pectinatus var. ochroleuca were general; Oreobolus pumilio was also found with the tiny dark green tufts of Juncella submersa, *Centrolepis monogyna, Liparophyllum Gunnii, also Plantago tasmanica and *Ourisia integrifolia, in damp places.

\section{Low Mountain Forest.}

This association spread over the major and more sheltered portion of the summit plateau of Mt Read, but was limited on Mt Field W. to the western slopes of the Broad Valley. About 3-5 m. in height it seems to require deep peat and shelter and probably forms the succession to the dwarf mountain forest, showing an approach to the facies of the W. Coast mixed forest by the gradual segregation of those species which can develop into forest trees, with elimination of the ombrophobous shrubbery element. *Phyllocladus, *Athrotaxis setaginoides and *A. cupressoides, Atherosperma, Fagus Cunninghamii, Drimys, *Telopea with *Richea pandanifolia chiefly compose it. The trees are dwarfed and crowded with little undergrowth, but on Mt Read *Anemone crassifolia and the straggling *Archeria eriocarpa were conspicuous near Lake Johnson. This lake-3500', literally cut out of the peat-is surrounded by the Sphagnum encrusted edge, where the water dips at once to about $1 \mathrm{~m}$. 
in depth, red strands of *Sphagnum pseudo-rufescens, Myriophyllum pedunculatum, the latter bearing tufts of the little liverwort Lepidozia tenax, with Scirpus fluitans floating out densely from the sides. *Isoetes elatior, over $1 \mathrm{dm}$. high, grew in single tufts on the bottom, with Crantzia lineata creeping.

On Mt Field W. the trees were less crowded with more shrubby undergrowth, as would be expected from the lesser rainfall. The north-westerly slopes of the Broad Valley were covered with low forest composed of *Phyllocladus, *Athrotaxis selaginoides, Fagus Cunninghamii, Drimys, *Telopea, * Richea pandanifolia and some small Eucalyptus, sheltering several charming lakes, on whose immediate edge, behind the small dark *Phaerosphaera and Baeckia Gunniana, the pyramidal lines of the stately *Athrotaxis cupressoides against the dense foliage give a mysterious remote effect to these forestembedded mountain lakes, always reminding me of Böcklin's painting "Die Toteninsel," so often reproduced in German prints.

The segregation of *A. cupressoides to lake margins and river banks marks the limits of its distribution eastwards.

\section{Small Eucalyptus Scrub.}

On the exposed summit plateau of Mt Field E., this association, apparently secondary in character, replaced the open dwarf mountain forest of Mt Field W. Low parallel ridges, relics of the former level, bore these trees with a sparse undergrowth of chiefly Pernettya tasmanica, Pentachondra pumila and some larger shrubs, such as Coprosma nitida and *Olearia pinifolia.

At the base of Mt Field E., a group of open Eucalyptus sheltered the * Microcachrys, growing in cushions formed by massing so thickly over stones that it appeared clipped, but though visited several times in December and January, no cones were seen on these plants. As *Microcachrys normally grows in the open, its presence in sterile condition with Eucalyptus suggested survival under alien conditions.

On the southern side of Lake Fenton, small Eucalyptus trees shaded the edge of the mixed mountain shrubbery, where some shrubby *Phyllocladus, Drimys, little thickets of *Fagus Gunnii and small groups of *Richea pandanifolia, with a few *Athrotaxis selaginoides, the most easterly station of the three latter plants, seemed to point to a former open dwarf mountain forest station, which as the result of fires, had gradually yielded to small Eucalyptus scrub.

Around the hut, situated on the forest side of Lake Webster, erected by the Government for the accommodation of tourists, a great deal of cutting out of wood has naturally resulted and fires started which have, to a certain extent, burnt out the original vegetation, so that what was possibly low forest is now a secondary scrub, quite dry in character.

Under a screen composed of small Eucalyptus species, Hakea acicularis, *Orites acicularis, $* O$. revoluta, and $* O$. diversifolia, Banksia serrata were like 
small trees, while Sprengelia incarnata, *Richea sprengelioides, white Epacris, the spreading Bauera and the fragrant Boronia pinnata, with brown patches of *Exocarpus humifusa constituted some of the smaller undergrowth. The generally distributed peculiar spongiose lichen, Cladonia retepora, limited to the southern hemisphere, on the ground, and Fuligo septica, in what Miss Lister considered very large examples, but apparently the usual size in this country, about $1 \mathrm{dm}$. long, $8 \mathrm{~cm}$. high and somewhat more across, on dead wood and leaves, were very abundant.

From this secondary scrub a tongue of pure Eucalyptus on dry shingle slopes, with Gentiana saxosa chiefly as undergrowth, stretched up to the plateau, palpably a secondary growth, the result of fires, as a large area of low mixed forest bordering it on the north had been recently burnt off.

Ultimately, therefore, these monotonous and uninteresting trees will dominate the summit plateaux to the exclusion of the autochthonous flora, as is already the case on the Central Lake Plateau.

On the summit plateau of Mt Hartz, by Lake Esperance, while *E. vernicosa, a small dense shrub, was dominant on one side, light scrub of $* E$. coccifera bounded the rest of the lake, of which the immediate vicinity had been spared by the fire.

On Mt Wellington where much drier conditions prevail than on the other mountains, small open Eucalyptus with shrubby undergrowth obtains up to the very crest of the summit plateau. Above the huge stonefield, or "Ploughed Field," the peculiar $* E$. coccifera, with branches often red stemmed, shelters shrub growth of which *Lomatia polymorpha, Baeckia Gunniana, *Trochocarpa thymifolia, and Styphelia montana were most conspicuous, the $* E$. coccifera even persisting, in dwarfed horizontal form, on to the summit plateau itself.

In small rock pools on the open top, the water was quite red from the gelatinous masses of the blue-green alga Gloeocapsa sanguinea (Ag.), Kütz.

\section{PHYTOGEOGRAPHICAL CONCLUSIONS.}

In the preceding pages De Candolle ${ }^{1}$ and Drude ${ }^{2}$ have been followed in describing as Boreal all floral groups north of the Tropic of Cancer, while Austral stands for all formations south of the Tropic of Capricorn.

Within these latitudes we have the boreal-arctic and sub-arctic, and the austral-antarctic and sub-antarctic zones, including boreal-montane and austral-montane plants.

Skottsberg $^{3}$ concludes that it is necessary to distinguish between the antarctic treeless islands that lie beyond the 60 th parallel and the sub-antarctic zone, which would extend from the 40th to the 60th parallel, comprising Tasmania, the south-eastern or mountainous portion of the South Island of

1 A. de Candolle. Géographie Botanique, Paris, r. 1855, p. 552.

2 Oscar Drude. Die Florenreiche der Erde, p. 23.

3 Carl Skottsberg. Loc. cit. Ymer, 1905, pp. 402-427, Tafl. 7. 
New Zealand, Tierra del Fuego and the extreme south of the Cordillera of the Andes, all characterised by evergreen beeches.

Further, in summarising the different views expressed in previous work on the antarctic region, he points out that "Drude ${ }^{1}$ evidently used the term 'antarctic flora' in order to designate a floristic physiognomical group of plant species, occurring here and there under special conditions, rather than as a geographical dominion $2 "$; a view which aptly describes the relation of these plants to the austral-antarctic region.

The plants in question, ombrophobous in habit, requiring low temperature, intense illumination with heavy rainfall for their development, are limited to high altitudes, above tree level in normally forest clad regions; but in the treeless zone of the antarctic these conditions of habitat are found at sea-level.

The countries included in the sub-antarctic zone project as narrow tongues of land into the vast expanse of the antarctic seas. Dominated by low summer temperature and perpetual westerly winds, they show a resultant faunal and floral paucity of types and specific differentiation, with extreme modification to enable them to withstand constant adverse conditions; for it has been well said: "Der Wind mit niedriger Temperatur gepaart, unter allen ungunstigen klimatischen Factoren in gestörender Wirkung obenan steht ${ }^{3}$."

Edaphically, in the absence of an annual leaf fall, the only exception being three very localised microphyllous beeches, there can be no progressive amelioration of soil conditions; further, considering the absence of all leguminous plants which act as nitrifying agents, the persistently xerophilous type of this vegetation is not surprising. Not a single member of this family, so well represented in the boreal-montane flora, is present in the austral-montane element in Tasmania and the same holds for the New Zealand Alps and sub-antarctic islands of America ${ }^{4}$.

It is not surprising therefore that herbaceous plants, which, as Hesselmann ${ }^{5}$ demonstrates, are present in proportion to the extent of nitrification in the soil, should under these circumstances be very sparsely represented; the few members of this class of plants being chamaephytes, with hemicryptophytes rare in comparison.

It is strange that these factors in southern latitudes, emphasised by all observers from Ross onwards, should not have been taken into account by Sinnott and Bailey ${ }^{6}$ when they state "the climate of Tasmania in the extreme south is very similar to that of England. Despite this temperate character

1 Oscar Drude. Pflanzengeographie, 1890, p. 491.

2 Garl Skottsberg. Loc. cit. p. 404.

${ }^{3}$ H. Schenck. Loc. cit. p. 8.

4 Loc. cit. p. 33.

5 H. Hesselmann. "Studien über Nitratbildung in natiirlichen Böden und ihre Bedeutung in pflanzenökologischer Hinsicht." Mitt. der schwed. forst. Versuchsanstalt, Stockholm, 1917, Heft 13-14, pp. 297-422. Rev. in Bot. Zeitsch. x. H. 7, pp. 400-402. [See notice in this JoURNaL 7, p. 210.]

6 Sinnott and Bailey. "The Origin and Dispersal of Herbaceous Angiosperms." Ann. Bot. xxvIII. pt. 2, p. 583. 
of the climate, woody plants are very much more abundant there than in the corresponding regions of the northern hemisphere, consisting from 50 to 75 per cent. or more of the dicotyledonous vegetation. Tasmania has four or more times as great a proportion of woody plants as Great Britain. The Flora of the endemic genera contains a still smaller percentage of herbaceous plants."

\section{Distribution and Derivation of the Austral-montane Flora.}

Various hypotheses have been brought forward to account for the presence of this physiognomic group of plants in the scattered lands of Austral-antarctica.

This question has been however tersely summarised by Schenk ${ }^{\mathbf{1}}$ as follows: "Mit der Annahme einer der Südspitzen der Kontinente verbindener Antarktis sind die ungeheuren Tiefen unvereinbar, welche die deutsche Tiefsee-Expedition da wo dieses Südpolar-land sich erstrecken sollte, nachwies; mit der Annahme einer von der jetzigen wesentlich abweichenden Konfiguration, wenigstens seit Beginn der Tertiärzeit, ist die Flora und Fauna der subantarktischen Insel unvereinbar, denn ihr Character lässt sich dadurch erklaren, dass sie, wie gegenwärtig, auch früher, wenigstens so weit zurück als die Geschichte ihren jetzigen Flora und Fauna reicht, ganz vereinzelt im Ozean lagern und nur durch den stürmischen Westwind miteinander in Verbindung standen."

Pfeffer ${ }^{2}$ is further quoted from the zoological side as holding the same opinion: "Es hat demnach nie in Süden, in neueren Zeiten, eine Landesausdehnung gegeben welche sich irgendwie mit der des arktischen Gebietes vergleichen könnte; sonst hätten zahlreiche Tiere an der Ufern entlang ihre cirkumpolare Verbreitung finden miissen." A point of view further supported by mineralogical evidence $^{3}$ : "It is therefore permissible perhaps to infer that the Tasman sea is of great age, especially in its more southern portions, inasmuch as it appears to have been a barrier to common or related ore deposition between Australasia and New Zealand through the ages."

The possibilities of any but an "opportunity4" exchange of plants since the Tertiary period between South America and other austral-antarctic lands with the same floral elements in common, have been emphatically discounted by Berry's ${ }^{5}$ recent work of which "the facts indicate that in Bolivia the great ranges of the Andes have been elevated from low altitudes since some time in the Pliocene. Tertiary deposits on the high eastern ranges are found on the evidence of the Flora to be no older than this epoch. These beds now lie from $13,000 \mathrm{ft}$. to $15,000 \mathrm{ft}$. above sea-level in a cold, intra-montane basin, but the

1 H. Schenck. Loc. cit. pp. 63-64. $\quad{ }^{2}$ Loc. cit. p. $65 . \quad{ }^{3}$ E. C. Andrews. Loc. cit. p. 776.

4 L. S. Gibbs. "A Contribution to the Flora and Plant Formations of Mt Kinabalu and the Highlands of Brit. N. Borneo." Journ. Linn. Soc. Bot. XLII. 1914, p. 19.

5 E. W. Berry. "Fossil Plants from Bolivia and their bearing upon the age of uplift of the Eastern Andes." Map, ills. Proc. U.S. Natl. Museum, 54, 1917, pp. 103-164. Rev. in Geogr. Review, May, 1919, pp. 353-354. 
fossil plants they contain resemble those still living in the Amazonian forest and grew in a warm humid climate at a low elevation"; while the evidence of marine fossils from the same series of beds near Potosì shows actual submergence at about the same period. Berry further states: "The geological history of Panama, Peru, Chile, Patagonia and Graham Land shows widespread submergence in the Pliocene, corresponding to the Bolivia occurrences."

Comparing these results with those of Noetling, already referred to, we can only conclude that the Andes rose out of tropical surroundings previous to the period when Tasmania, much reduced in size and wholly glaciated, could support little or no plant life.

We can only assume that both these regions have derived their plant covering under the same conditions proved to obtain under similar circumstances $^{1}$ in our own times, for there is little reason to suppose that the active agent of to-day should not have been equally potent in Tertiary times, and that then as now, these regions had "no agent but the wild west wind in common" to colonise their pristine wastes, the more so, as in both cases the necessarily very limited effects of ocean currents must be ruled out of consideration for mountain plants.

The potency of this agency is acknowledged by Hooker ${ }^{2}$, who wrote in relation to Tierra del Fuego: "It presents a Flora characterising isolated groups of islands, extending for 5000 miles to the eastwards of its own position; some of these detached spots are much closer to the African and Australian continents, whose vegetation they do not assume, than to the American, and they are situated all in latitudes and under circumstances eminently unfavourable to the migration of species save that their position relatively to Fuegia is in the same direction as that of the violent westerly winds."

\section{Papuan derivation of Austral-montane Plants.}

Attention has already been called in a previous work ${ }^{3}$ to the marked relation between the mountain flora of North-West New Guinea and the so-. called "antarctic flora" of the southern hemisphere.

Taking the typical genera in this group not known in boreal regions, present in Tasmania, we can count Carpha, Oreobolus, Juncella, $\dagger$ Centrolepis, *Gaimardia, *Astelia, Fagus, Lomatia, Colobanthus, †Drimys, *Acaena, $\dagger$ Drapetes, * Gunnera, † Leptospermum, † Oreomyrrhïs, Dichosciadium, Aciphylla, Azorella, \$Styphelia, Dracophyllum, Archeria, *Pratia, Forstera, Ourisia, $\uparrow$ Coprosma, Donatia, *Olearia, $\uparrow$ Lagenophora, Pterygopappus, *Abrotanella 4 and Raoulia.

1 H. Schenck. Loc. cit. p. 67.

2 J. D. Hooker. Bot. Ant. Voy. 1. Fl. Ant. pt. ii. p. 211.

3 L. S. Gibbs. Phytog. Dutch N.W. New Guinea, loc. cit. p. 39. [See Review in this JournaL 6, p. 157.]

4 Fenry N. Ridley. "Report on the Botany of the Wollaston Expedition to Dutch New Guinea." Trans. Linn. Soc. Ix. I. ser. ii. 1916, p. 86. 
Those marked with $a^{*}$ are common to the mountains of New Guinea, while a $\dagger$ denotes $\mathrm{N}$. Borneo or the Philippines, and a $\ddagger$ shows those genera now proved to be dominant in New Guinea.

Since working out my own results, further light has already been thrown on this question by the discovery in the Charles Louis Range in S.W. New Guinea, not only of Centrolepis nova-guineensis, but also of a new species of $G_{\text {Gimardia }}{ }^{1}$ : while Oreomyrrhis borneensis ${ }^{2}$, very near $O$. andicola, has been described from the summit of Kinabalu in N. Borneo.

It is also now possible, thanks to the admirable work of Griffith Taylor ${ }^{3}$ and his power of lucid exposition, to advance definite proof of meteorological conditions, which would not only control the distribution due southwards of these Papuan mountain plants, but also in a south-easterly direction over New Zealand and S. America as well. In tracing possible tracks for modern airmen, this author has revealed to botanists the well-worn paths of ancient plants from time immemorial. He writes as follows: "The trade wind in $\mathrm{N}$. Queensland blows on an average about 20 miles an hour for weeks at a time, but its velocity is probably less in other portions of the belt. The layer of trade wind is of limited thickness, for above it blows a poleward return wind. This is reached about $12,000^{\prime}$ above sea-level near the tropics (according to German data) but is lower in temperate regions. It is often reached in ascending $4000^{\prime}$ above Melbourne, and high regions like Mt Kosciusko experience the west wind very frequently."

Once we assume that the configuration of the austral-antarctic lands has remained the same since Tertiary times, we may infer that this has also been the case with the remarkably stable meteorological phenomena as now known. We may therefore be justified in attributing the same agency to the persistent north-west wind of high altitude over the mountains of New Guinea as has already been conceded to the westerly winds of the antarctic regions.

Rising in the N.E. of India ${ }^{4}$, the N.W. wind would also account for the incidence of the boreal plants of the Himalayas on the isolated peaks of the Malay Archipelago, the New Guinea mountain ranges and southwards through the austral-antarctic region, and thus justify the presence of Ranunculus, Anemone, Caltha, Geum, Rubus, Cardamine, Lagenophora, Euphrasia and Senecio on the Tasmanian summit plateaux.

The direction and comparative height of this wind are graphicallyillustrated in Figs. 2 and $3^{5}$. Blowing obliquely from the N.W. to the S.E. across the Australian continent we may assume it includes New Zealand and extreme S. America in its area. All the year round, as constant in direction as the

1 W. B. Turrill. Nova Guinea inedit.

2 E. D. Merrill. Amer. Journ. Bot. 5, pp. 514-15, 1918. Pl. XXXVI.

3 Griffith Taylor. "Air Routes to Australia." Geogr. Review, April, 1919, p. 259, figs. 1-3.

4 Loc. cit. p. 260 , fig. 2. 5 Loc. cit. p. 261. 
westerly winds of the antarctic region, there is little doubt this wind must have had the same predominant effect in the distribution of plants along its altitudinal range. It is significant that the gradual lowering of height in its progress southwards corresponds with the presence of the only stations in Australia where the necessary conditions controlling possible habitats for the austral-montane plants obtain, viz., the summit of Mt Kosciusko, at $7000^{\prime}$ in New South Wales and those of the mountains of Victoria, Mts Baw Baw, Munyong, Cobberas, Buffalo, etc., of the same range; all limited in extent, and from $5-6000^{\prime}$ in height.

Further south, we have the Tasmanian mountain summit plateaux at still lower altitudes, with the New Zealand and S. American alpine regions, but these countries would come equally within the domination of the circumpolar westerly winds.

There are therefore two constant agencies to reckon with in the distribution of plants throughout the austral-antarctic region, viz., the north-westerly poleward wind which sweeps persistently over the mountains of New Guinea above the tree level, in a constant direction and at a constant altitude, and the equally persistent westerly winds and gales of the antarctic seas. Consequently seeds transported by the former agency would be precipitated in southern latitudes, where, once established, they remain within the radius of the circumpolar wind, with no possibility of return.

We find these same or related plant elements not only well established on widely separated lands and islands, but also showing a certain range of differentiation on parallel lines, indicating not only the enormous period of time the plants must have flourished in their present stations, but also the persistency of environmental conditions which could control the conspicuous parallelism or convergence displayed.

\section{Geological Evidence for the Sequence of Development and Distribution.}

For any estimate of chronological sequence in floral development we are thrown entirely on geology, as geological change controls climate, and climate again controls the nature of the resultant plant covering $\mathbf{1}$.

In the case of the austral-montane plants under discussion, in geological sequence the present configuration of the New Guinea ranges dates from Tertiary times, the South American Cordillera according to present geological

1 In relation to this question I am indebted to Dr Smith-Woodward for the following data: "We find in New Guinea typical marine Miocene fossils occur at a height of 14,000 ft., so that the mountains there have been raised to that extent in the latter half of the Tertiary period. It is extremely likely that some of this rising is even so late as the Pleistocene. We find the Rocky Mts, as well as the Andes, have certainly risen much during the late Pliocene and Pleistocene times."

Journ. of Ecology VIII 
data, was raised from below sea-level in the Quaternary period, approximating to the epoch in which Tasmania assumed her present form.

The mountains of New Guinea, therefore, on the strength of both geological and meteorological data, may be considered as the focus of development and distribution of the so-called "antarctic" plants, justifying the term Papuan austral-montane for this group, of which, even on the limited basis of our present knowledge, nearly one-half of its most characteristic genera are now known from New Guinea. This number will increase in proportion as further work on the vast and barely known ranges of that country add to the little knowledge we possess of their plant covering between the tree and the perpetual snow levels.

One must accept the fact that such a characteristic flora has had little chance of further development in the scattered austral-antarctic lands to which it has so far been considered localised. In the case of New Zealand and S. America diversified physiographical conditions have favoured both greater entomological possibilities and more varied systematic divergence, with the result that genera elsewhere restricted to one or two types, have developed much greater specific differentiation, though always on CONVERGENT LINES.

For adequate appreciation of the splendid work of Tasmanian botanists, reference is made to the accounts of Hooker ${ }^{1}$ and J. H. Maiden ${ }^{2}$. The thoroughness of that work may be judged from the fact that the present collection has only yielded a new Morchella, $M$. tasmanica Ramsbottom, with a very few new records in the local distribution of plants.

My thanks are due to the Government for facilities afforded in Tasmania; to Professor Flynn and Mr L. Rodway for their ever-ready kindness; also to Miss G. Lister and Messrs G. S. West, J. Ramsbottom, A. Lorrain Smith, C. H. Wright and R. A. Rolfe for the determination of Myxomycetes, fresh water algae, lichens, the new Morchella and mosses, liverworts and Orchids respectively. Also to the authorities at Kew for the courtesy shown while working out this collection there, to the British Museum for many facilities afforded and to Dr Smith-Woodward, F.R.S., for data quoted. The plants enumerated may be consulted at Kew and the British Museum.

SYSTEMATIC ENUMERATION OF SPECIES COLLECTED ON THE MOUNTAIN SUMMIT PLATEAU AND IN THE MIXED FOREST OF TASMANIA. FROM SEPTEMBER TO MARCH, 1914-15.

\section{Mycetozon (G. Lister).}

Lamproderma columbinum (Pers.), Rost. W. Coast, Lake Bellinger, 500', near Strahan, damp wood. Oct. 6834. Distrib. Europe, N. America, Japan.

1 J. D. Hooker. Bot. Ant. Voy. 3. Fl. Tas. i. p. exxv.

2 J. H. Maiden. "Records of Tasmanian Botanists." Proc. R. Soc. Tas. pp. 9-29, 1909. 
Freshwater Algae (G. S. West).

Gloeocapsa sanguinea (Ag.), Kütz. Mt Wellington, summit plateau, 4100', brown-red, filling pools of water. Dec. 6540. A blue-green alga with bright red sheaths around it. Distrib. Boreal regions, England, Tyrol, Austria and Riesengebirge.

\section{Fungi (J. Ramsbottom).}

Morchella tasmanica n. sp.

Ascomate oblongo-conico, acuto, c. $3 \mathrm{~cm}$. longo, $1.5 \mathrm{~cm}$. crasso, basi stipitis diametrum vix excedente, pruinoso, costis primariis longitudinalibus, subparallelis, acie obtusis, atro-castaneis, alveolis fulvis, secundariis transversis, pliciformibus, irregularibus; stipite subaequali et ad basim non incrassato, versus apicem parum crassiori, c. $9 \mathrm{~cm}$. longo, $1 \mathrm{~cm}$. crasso, fulvo velutino, toto pube brevi fulvo tecto; pilis variabilibus, septatis, ad apicem vix incrassatis, c. $20 \mu$ crassis; ascis cylindraceis, ad basim subattenuatis, octosporis, $350-400 \mu \times 22-24 \mu$; sporis late ellipsoideis, hyalinis vel hyalinoochraceis, $27-32 \mu \times 15-16 \mu$; paraphysibus ramosis, septatis, hyalinis vel hyalino-ochraceis, ad apices vix incrassatis, $15-17 \mu$ crassis.

In terra uda.

In light Eucalyptus forest.

Mt Dromedary, 3000', New Norfolk. Nov. 6833.

LiChenes (A. Lorrain Smith).

Baeomyces ramalinellus Nyl. W. Coast, Teepoukana, King River, 500', rocks and banks in open cuttings. Oct. 6382. Distrib. S. America (Chile).

Cladonia retepora (Labill.) Floerke. First published as Baeomyces retepora, though usually quoted under Cladonia as $C l$. retipora.

Mt Field W., near Lake Webster, 3500', open Eucalyptus scrub, common. Dec. 6557. Distrib. Australia, Chatham and Campbell Islands, N. Zealand N. Caledonia.

Hepaticae (C. H. Wright).

Lepidozia tenax Lindenburg (Jungermannia tenax Greville, in Ann. Lyceum Nat. Hist. New York, I. 1824, p. 277, t. 23). W. Coast, Mt Read, summit plateau, $3500^{\prime}$, in Lake Johnson, on floating branches of Myriophyllum pedunculatum. Veg. Oct. 6442. Distrib. S. Huon, Macquarie Harbour, St Patrick's River; Lord Auckland's Group.

\section{Sphagnaceae (C. H. Wright).}

*Sphagnum cf. pseudo-rufescens Warnst. W. Coast, Mt Read, summit plateau, Lake Johnson, 3500', submerged on edge of lake-long reddish floating branches. Veg. Oct. 6445. Distrib. Mt Wellington, Oyster Cove, Western Tiers, Alma Tiers. 
LYCOPODIACEAE.

Lycopodium varium $\mathrm{R}$. Br. Mt Maria, summit plateau, 2300', on rocks. Fr. Sept. 6845. Distrib. General; Vict., N.S.W., N. Zealand, Lord Howe's Island.

Lycopodium scariosum Forst. W. Coast, Mt Read, summit plateau, 3600', in open shrubberies. Veg. Oct. 6433. Distrib. Mt Wellington; Vict., N. Zealand, New Guinea, Philippines.

\section{ISOETACEAE.}

*Isoetes cf. elatior F. Muell. in herb. Sonder. W. Coast, Mt Read, 3500', summit plateau, Lake Johnson, submerged, abundant. o o o. Oct. 6441 (plant $1 \mathrm{dm}$. high). Distrib. South Esk River.

\section{CONIFERAe.}

*Phaerosphaera Hookeriana Archer. Mt Field E., summit plateau, round Lake Fenton and tarns above, 3500'. Oct. 6516. Mt Field E., summit plateau, above Ellendale, lining streams and boggy areas. Jan. 6584. Distrib. Lake St Clair, Mts Field E. and W., La Perouse, Western and Craḍle Mts.

*Microcachrys tetragona Hook. f. W. Coast, Mt Read, 3600', summit plateau, shrubberies, carpeting the ground where open. \& (old). Oct. 6431. Mt Field W., summit plateau, 3500', open shrubberies. ơ ㅇ. Dec. 6567. Distrib. Summit plateaux.

*Dacrydium Franklinii Hook. f. W. Coast, Teepoukana, 500-1000', King River, mixed forest and along edge of river. o o $^{*}$. Oct. 6365 . Seedlings. 6376. Distrib. S. and W. Coasts, principally along river courses.

Podocarpus alpina R. Br. Hartz Mts, Pinnacle, 4300', spreading massed over rocks. Feb. 6794. Distrib. Mt Wellington, Marlborough, River Mersev, summit Mt Olympus, Huon River above high water mark; Vict., N.S.W.

*Phyllocladus aspleniifolius (Labill.) Hook. f. W. Coast, Teepoukana, 500 ', King River, mixed forest. ㅇ. Oct. 6377. Mt Field E., upper forest slopes below Lake Fenton, 2500'. Nov. 6518. Mt Field E., slopes above Ellendale, 2500'. Jan. 6583. Distrib. Common in mixed forest.

*Athrotaxis cupressoides Don. W. Coast, Mt Read, summit plateau, 3600', low mountain forest. Fr. Oct. 6438. Distrib. Lake St Clair, Pine River, nr Marlborough, Western Mts, Dane River, Mt Field W.

*Athrotaxis laxifolia Hook. Mt Read, summit plateau, 3600', dwarf mountain forest. \%. Oct. 6432. Distrib. Western Mts, Meander River, Mt Field W. and near La Perouse.

*Athrotaxis selaginoides Don. West Coast, Teepoukana, 500', King River, mixed forest. Fr. Oct. 6388. Distrib. Western Mts, Mts Field, Hartz, La Perouse, Olympus, Sorell, Meander Falls, Lake St Clair and W. Coast.

*Diselma Archeri Hook. f. W. Coast, Mt Read, summit plateau, 3600', open shrubberies. Oct. 6434. Mt Field W., 4500', forming thickets on east 
slopes of summit ridge. Dec. 6574. Distrib. Summit plateaux, round Lake St Clair and Meander Falls.

\section{Cyperaceae.}

Oreobolus pumilio R. Br. Mt Field W., summit ridge, 4700', amongst level plant mosaics. Fr. Dec. 6572. Hartz Mts, summit plateau, 4000', forming small cushions. Fr. Feb. 6807. Distrib. Summit plateaux; Vict., N.S.W., N. Zealand, S. America.

\section{Centrolepidaceae.}

Juncella submersa (Hook. f.) Hieron. Hartz Mts, summit plateau, 4000', edge of lake. Fl. Feb. 6809. Distrib. Macquarie Harbour, South Esk River, Western Mts; Vict., N.S.W.

*Centrolepis monogyna Benth. Hartz Mts, summit plateau, $4000^{\prime}$, by stream. Fl. Feb. 6810. Distrib. Marlborough, Lake St Clair, Mt Dundas, between Zeehan and little Henty River.

\section{LILIACEAE.}

Herpolirion novae-zelandiae Hook. f. Mt Field E., summit plateau, 3500'. Fl. Jan. 6866. Distrib. Western Mts, Hampshire Hills, Lake St Clair, Hamilton; Vict., N.S.W., N. Zealand.

*Hewardia tasmanica Hook. f. Frenchman's Cap, near Pinnacle, 3500'. Jan. (R. A. Black's Coll., "near mountain summits, southern and western," 90.) Distrib. Mt La Perouse, Arthur Range to W. Coast.

\section{Amaryllidaceae.}

*Campynema lineare Labill. Mt Field W., Broad River, near Lake Webster, $3000^{\prime}$. Fl. Dec. 6555. Distrib. Mt Field, Southport, Recherche, W. Coast.

\section{Orchidaceat (R. A. Rolfe).}

Prasophyllum fuscum R. Br., var.? Hartz Mts, summit plateau, 4000', nr Pinnacle, on billowed plant mosaics. Fl. Feb. 6793.

\section{Fagaceat.}

*Fagus Gunnii Hook. f. Mt Field W., summit plateau, in thickets or scattered, 3500-4400'. Fl., Fr. Dec. 6561. Distrib. Mts La Perouse, Olympus, Sorell, Field, Read, Cradle Mountain.

Fagus Cunninghamii Hook. W. Coast, Teepoukana, King River, 500', mixed forest. Fl. Oct. 6416. Distrib. General in mixed forest; Victoria.

\section{Proteaceat.}

*Bellendena montana R. Br. Mt Field W., 3500', summit plateau. Fl. Dec. 6550. Distrib. Marlborough, Arthur's Lakes, Great Lake, Lake St Clair, summit plateaux.

*Cenarrhenes nitida Labill. W. Coast, Teepoukana, King River, 500', undershrub in forest. Fl., Fr. Oct. 6429. Distrib. Mixed forest of S. and W. 
* Orites diversifolia $\mathrm{R}$. Br. Mt Field E., summit plateau, shrubberies round Lake Fenton, 3500'. Fl. Nov. 6511. Mt Wellington, summit plateau, 4000', in shrubberies. Fl. Dec. 6529. Distrib. Summit plateaux.

*Orites Milligani Meissn. Mt Read, summit plateau, 3600', dwarf mountain forest. Fr. Oct. 6447. Distrib. Mts Sorell, Dundas, Read, La Perouse.

*Orites revoluta $\mathrm{R}$. Br. Mt Field E., summit plateau, abundant in shrubberies round Lake Fenton, 3500'. Fl., Fr. Oct. 6510. Distrib. Summit plateaux.

*Orites acicularis R. Br. Mt Field E., Lake Fenton, 3500', summit plateau, shrubberies and under small Eucalyptus scrub. Fl. Nov. 6512. Distrib. Summit plateaux.

*Hakea epiglottis Labill. Mt Field W., common undergrowth by hut, Lake Webster, 3000', Fr. Dec. 6558. Distrib. Very common.

* Telopea truncata R. Br. Mt Read, Lake Johnson, 3500', low mountain forest. Fl., Fr. Oct. 6440. Distrib. Dwarf and low mountain forest and shrubberies of summit plateaux.

\section{Santalaceae.}

*Exocarpus humifusa R. Br. Mt Field E., summit plateau, Lake Fenton, 3500 ', shrubberies, spreading over stones. Fr. Nov. 6509. Distrib. Western Mts, Mts Wellington, La Perouse, Dundas.

\section{RanunCUlaceat.}

*Anemone crassifolia Hook. f. W. Coast, Mt Read, Lake Johnson, 3500', scattered undergrowth in low mountain forest. Fl. Oct. 6437. Distrib. Fatigue Hill, Black Buff, Zeehan, mountains W. of Lake St Clair, La Perouse and range W. of Adamson's Peak.

\section{Monimiaceae.}

Atherosperma moschatum Labill. Mt Read, low mountain forest round Lake Johnson, 3500'. Fl., Fr. Oct. 6449. Distrib. General in mixed forest; Vict., N.S.W.

\section{CructFerae.}

* Cardamine radicata Hook. f. Central plateau, Mount Olympus, damp, shaded couloirs between summit columns, 4000'. Fl. Jan. 6597. Distrib. Mts Olympus, La Perouse, Humboldt.

\section{Droseraceae.}

Drosera pygmaea DC. Mt Field W., 3000', Broad River, near Lake Webster, damp sand. Fl. Dec. 6849. Distrib. Very common; N.S.W. to S. Australia.

Drosera peltata Sm. var. gracilis Benth. Mt Field W., Broad River, near Lake Webster in damp sand, 3000'. Fl. Dec. 6559. Distrib. (of var.) Hampshire Hills, Formosa, Marlborough, Arthur's Lakes, Cambridge; N.S.W. 


\section{Saxifragaceat.}

* Tetracarpaea tasmanica Hook. f. Slopes of Mt Olympus, 3500', under open Eucalyptus. Fl., Fr. Jan. 6595. Hartz Mts, upper forest slopes, 3500'. Fl. (white), Fr. Feb. 6797. Distrib. General in uplands and on summit plateaux.

*Anopterus glandulosus Labill. Tasman Peninsula, in forest valleys. Fl. Oct. 6372. Distrib. General in mixed forest.

Bauera rubioides Andr. Mt Field W., banks of Broad River, 3000'. Fl. (double) Dec. 6551. Hartz Mts, Majendie Plains, massed in open, 2000'. Fl. (double) Feb. 6806. Distrib. Common everywhere; Vict., N.S.W.

\section{Pittosporaceae.}

Pittosporum bicolor Hook. Maria Island, plateau summit, 2300', shrubberies between broken diabase. Veg. Sept. 6395. Distrib. Abundant in forest; Vict., N.S.W.

\section{Cunoniaceae.}

*Anodopetalum biglandulosum A. Cunn. Hartz Mts, slopes of, straggling, erect or decumbent undershrub, 2-3000'. Fl. Feb. 6790. Distrib. Mixed forest.

\section{Rosaceae.}

*Rubus Gunnianus Hook. f. Mt Field E., Lake Fenton, 3500', between stones. Fl. (white) Nov. 6508. Distrib. Summit plateaux.

\section{Oxalidaceae.}

Oxalis magellanica Forst. W. Coast, Mt Read, $3900^{\prime}$, creeping in open, where damp. Fl. Oct. 6448. Distrib. Summit plateaux in damp places; Vict., N.S.W., N. Zealand, Fuegia and S. Chile.

\section{Rutaceae.}

*Acradenia Franklinii Kipp. W. Coast, Teepoukana, King River, undershrub in mixed forest. Fl. Oct. 6379. Distrib. Gordon, Franklin and Pieman Rivers, Strahan.

\section{Rhamnaceae.}

* Spyridium ulicinum Benth. Mt Dromedary, summit, 3200', in open amongst rocks. Fl. Nov. 6482. Distrib. New Norfolk, Mt Dromedary, Mt Wellington, Hamilton, Launceston.

\section{ELAeocarpaceat.}

*Aristotelia peduncularis Hook. f. W. Coast, Strahan, undergrowth in mixed forest. Fl. Oct. 6417. Distrib. Mixed forest of S. and W., Mt Wellington, Arthur's Lakes, St Patrick's and Franklin Rivers. 


\section{EUCRYPHIACEAE.}

*Eucryphia Billardieri Spach. Summit plateau and slopes of Hàrtz Mts, small tree by streams, shrub in open, 2-4000'. Fl., Fr. Feb. 6792. Distrib. Mixed forest of the W. and S.

\section{Thymeliaceae.}

*Pimelia sericea R. Br. Mt Wellington, summit plateau and under "Organ Pipes," 3500-4100', amongst broken diabase. Fl. (pink) Dec. 6527. Distrib. General towards summit plateaux.

\section{Myrtaceae.}

*Eucalyptus coccifera Hook. f. Mt Wellington, 3900', towards summit plateau, in parts. Fl. Dec. 6541. Distrib. Some summit plateaux.

*Eucalyptus vernicosa Hook. f. Hartz Mts, summit plateau, 4000', on edge of Lake Esperance. Fl., Fr. Feb. 6798. Distrib. Mts La Perouse, Fatigue, Direction and Arrowsmith.

Leptospermum lanigerum Sm. var. grandifolium Benth. Hartz Mts, summit plateau, 4000', by two lakes, in open. Fl., Fr. Feb. 6801. Distrib. Macquarie Harbour (Milligan, 714; Rocky Cape, Milligan, 813: Herb. Kew.) match the above exactly; N.S.W.

*Leptospermum rupestre Hook. f. Hartz Mts, the Pinnacle, $4300^{\prime}$, prostrate over rocks. Fl., Fr. Feb. 6800. Distrib. Summit plateaux.

Baeckia Gunniana Schau. Mt Field E., near Lake Fenton, 3500', edge of stream. Fl., Fr. Nov. 6513. Mt Wellington, 3900', where open amongst rocks. Fr. Nov. 6537. Mt Field W., shores of Lake Webster, 3000'. Fr. Dec. 6568. Distrib. Summit plateaux, Lake St Clair (abundant); Vict., N.S.W.

\section{ONAGRACEAE.}

Epilobium confertifolium Hook. f. Mt Field W., summit ridge, $4700^{\prime}$, creeping at base of and between rocks. Fl. (pink) Dec. 6571. Distrib. Summit plateaux; N. Zealand.

\section{Halorrhagaceae.}

Myriophyllum pedunculatum Hook. f. W. Coast, Mt Read, Lake Johnson, $3500^{\prime}$, branches floating from edge of lake. Oct. 6443. Distrib. Very common; N.S.W., N. Zealand.

\section{UMBELLIFERAE.}

Dichosciadium ranunculaceum (F. v. M.) Domin. Mt Olympus, 4000', under drips at base of greenstone columns of summit. Fl. (white) Jan. 6599. Distrib. Mts La Perouse and Sorell, Great Lake, Eldon Range; N.S.W. to S. Australia.

*Aciphylla pracumbens F. Muell. Hartz Mts, Pinnacle, 4300', forming bright green cushions, $.30 \mathrm{~m}$. across or large patches spreading over broken 
diabase, abundant. Fl., Fr. Feb. 6795. Distrib. La Perouse, Adamson's Peak, Mt Hartz.

\section{Ericaceae.}

Pernettya tasmanica Hook. f. Mt Field E., summit plateau, 3500', amongst rocks and on level plant mosaic cushions. Fl. Jan. 6578. Distrib. General on central plateau and summit plateaux; N. Zealand.

\section{Epacridaceate.}

*Prionites cerinthoides R. Br. W. Coast, Strahan, mixed forest, straggling up trees and over moss hummocks. Fr. Oct. 6466. Hartz Mts, upper forest slopes, 2-3000', encircling trees up to $10 \mathrm{~m}$., abundant. Fl. Feb. 6791. Distrib. Mixed forest.

*Richea sprengelioides F. Muell. Mt Field E., summit plateau, abundant round Lake Fenton, 3500'. Fl. (yellow) Nov. 6514. Distrib. Summit plateaux.

* Richea acerosa F. Muell. Mt Field E., summit plateau, above Ellendale, $3500^{\prime}$, amongst rocks, small shrub, $\cdot 25 \mathrm{~m}$. Fl. (white) Jan. 6577. Distrib. Top of Western Mts, Arthur's Lakes.

*Richea scoparia Hook. f. Mt Field E., summit plateau, 3500', round Lake Fenton. Fl. (red) Nov. 6503. Mt Field E., summit plateau, above Ellendale, in open and under upper trees. Fl. (white) Jan. 6549. Distrib. Mt Wellington, St Valentine's Peak, Surrey Hills, Middlesex Plains, Western Mts, Mt Sorell, near Hamilton.

*Richea dracophylla R. Br. Mt Wellington, "Springs" to "Organ Pipes" zone, in open and under small Eucalyptus sp. 2500-3500'. Fl. Dec. 6534. Distrib. General in sub-summit zones of S. and W.

*Richea pandanifolia Hook. f. Mt Field W., summit plateau, 3500', open dwarf mountain forest. Bud, Dec. 6562. Distrib. Mixed forest of the S. and W.

Epacris petrophila Hook. f. Mt Field E., summit plateau, 3500', edge of Lake Fenton. Fl. Oct. 6507. Distrib. Summits of Western Mts, Arthur's Lakes; Vict., N.S.W.

Epacris serpyllifolia R. Br. Mt Field E., summit plateau, 3500', round Lake Fenton. Fl. Oct. 6853. Distrib. Mt Wellington, near Huon River, Lake St Clair, Lake Arthur, summit of Western Mts, Campbell Town; Vict., N.S.W.

*Epacris mucronulata R. Br. W. Coast, King River, Macquarie Harbour, at water's edge. Fl. Oct. 6406. Distrib. Franklin River.

*Archeria eriocarpa Hook. f. W. Coast, Teepoukana, 500', on King River, straggling over moss hummocks in mixed forest. Fl. (pink) Oct. 6378. Mt Read, summit plateau, by Lake Johnson, $3500^{\prime}$, low mountain forest. Fl. Oct. 6446. Distrib. Macquarie Harbour, in mixed forest S.W. of Lake St Clair, banks of the Gordon, Cradle Valley, La Perouse.

* Archeria serpyllifolia Hook. f. Hartz Mts, summit plateau by Great Lake, 4000', amongst rocks. Fl., Fr. Feb. 6802. Distrib. Mts La Perouse, Sorell, Olympus, Dundas, Adamson's Peak, Humboldt, Cradle Mts. 
Styphelia montana F. Muell. Mt Wellington, source of South East River, $3900^{\prime}$, damp places in open. Fl., Fr. Dec. 6536. Distrib. Mt Wellington, near Lake St Clair; Vict., N.S.W.

* Styphelia glauca (Labill.) Gibbs. Mt Wellington, sub-summit zone, 25003500'. Fl., Fr. Dec. 6542. Distrib. Common on sub-summit forest slopes.

* Styphelia straminea (R. Br.) Spreng. Mt Wellington, above "Ploughed Field," 3900', shrubberies between broken diabase. Fl., Fr. Dec. 6538. Distrib. Summit plateaux and sub-summit slopes.

*Styphelia straminea (R. Br.) Spreng. var. macrantha Benth. Mt Olympus, $3500^{\prime}$, shrubberies between broken diabase. Fl. (cream), Fr. (red) Jan. 6596 . Mt Hartz, summit plateau, 4000', Great Lake, shrubberies. Fl. Feb. 6803. Distrib. Mt Olympus (sides), Meander Falls, Western Mts (of var.).

* Styphelia dealbata (R. Br.) Spreng. Mt Hartz, summit plateau and Pinnacle, amongst rocks, 4-4300'. Fr., Fl. 6799. Distrib. Mt Wellington, Frenchman's Cap, Mt Hartz and Ben Lomond summit plateaux.

Pentachondra pumila R. Br. Mt Field E. and W., summit plateau, 3500'. Fl. Dec. 6576. Distrib. Summit plateaux; Vict., N.S.W., N. Zealand.

* Trochocarpa disticha Spreng. W. Coast, Strahan, old corduroy road to Queenstown, 1000', in mixed forest. Fl., Fr. Oct. 6383. Distrib. Recherche Bay, Southport, Mt Bischoff, Huon, W. Coast.

*Trochocarpa thymifolia Spreng. Mt Wellington, above "Ploughed Field," $3500^{\prime}$, shrubberies under Eucalyptus. Fl., Fr. Mar. 6543. Mt Field E., summit crest above Ellendale, 3500'. Fl. (red), Fr. (blue) Dec. 6548. Distrib. Mt Wellington, Western Mts.

* Trochocarpa Gunnii Benth. Hartz Mts, upper forest slopes, abundant from 2-3000'. Fl. (white), Fr. (mauve) Feb. 6788. Distrib. Hampshire Hills, margin and S.W. of Lake St Clair, La Perouse, Mt Hartz, W. Coast.

\section{LOGANIACEAE.}

*Mitrasacme Archeri Hook. f. Mt Field E., summit plateau, 3500', edge of tarn above Lake Fenton. Fl. Nov. 6505. Mt Field W., summit ridge, 4700', in level plant mosaic. Veg. Dec. 6855. Distrib. Western Mts, Lake Fenton, Mts Humboldt, Adamson's Peak, La Perouse, Geikie, etc.

Mitrasacme montana Hook. f. Mt Wellington, summit plateau, 4000', bright green, prostrate patches in damp places. Fl. Dec. 6539. Distrib. Mt Wellington, Black Bluff, Recherche Bay; Victoria.

\section{Gentianaceat.}

Gentiana montana Forst. Mt Field W., slopes above Lake Webster, 32003500', under Eucalyptus trees. F]. Dec. 6560. Distrib. Western Mts, Hampshire Hills, near Launceston, Cradle Valley, St Patrick's, Hobart, Mt Wellington, New Norfolk; N.S.W. to S. Australia, N. Zealand, S. America. 
Liparophyllum Gunnii Hook. f. Mt Field W., summit plateau, creeping on muddy banks of Broad River near Lake Webster, 3000'. Fl. (white) Dec. 6556. Hartz Mts, summit plateau, 4000', in lagoon by Lake Hartz. FJ. Feb. 6808. Distrib. Lake St Clair, Arthur's Lakes, general by water on summit plateaux; N. Zealand.

\section{SCROPHULARIACEAE.}

Veronica nivea Lindl. Mt Wellington, "Organ Pipes," 3500', amongst broken diabase. Fl. (mauve) Dec. 6530. Distrib. Mt Wellington, Western Mts, Lake Arthur, etc.; Vict., N.S.W.

* Ourisia integrifolia R. Br. Mt Field E., summit plateau, bog above Lake Fenton, 3500'. Fl. (white) Nov. 6504. Mt Olympus, top of small couloir between diabase columns, 4000'. Fl., Fr. Jan. 6600. Hartz Mts, summit plateau, by Great Lake, 4000'. Veg. Feb. 6880. Distrib. Summit plateaux.

Euphrasia Brownii F. Muell. var. alpina F. Muell. Mt Field E., summit plateau, Lake Fenton, 3500', in open. Fl. (white, veined mauve) Nov. 6502. Mt Olympus, top of small couloir between diabase columns, 4000'. Fl. Jan. 6601. Distrib. Mt Wellington, Western Mts, Gordon River; Vict., N.S.W.

\section{Plantaginaceae.}

Plantago Gunnii Hook. f. Mt Field E., summit plateau, 3500', dotted on level plant mosaic cushions. Fl., Fr. Jan. 6582 (pilose). Distrib. Arthur's Lakes, Western Mts, Mt Field; Vict., N.S.W.

Plantago tasmanica Hook. f. Hartz Mts, 4000', summit plateau. Fr. Feb. 6804 (plants woolly). Distrib. Mt Wellington, Near Cumming's Head, Western Mts, Lake St Clair, Arthur's Lakes; Victoria.

\section{Campanulaceae.}

Wahlenbergia saxicola DC. Mt Field E., summit plateau, by track from Ellendale, 3500'. Fl. (blue) Jan. 6581. Distrib. Mt Wellington; N. Zealand.

\section{Goodentaceat.}

Scaevola Hookeri F. Muell. Mt Field E., Ellendale Creek, 3000', subsummit forest zone. Mt Field W., Broad River near Lake Webster, 3000'. Fl. Dec. 6570. Distrib. Rocky Cape, Hampshire Hills, Chilton, Lake St Clair, Mt Wellington; Vict., N.S.W.

\section{Candolleaceat ${ }^{\mathbf{1}}$.}

Donatia novae-zelandiae Hook. f. Mt Field W., summit ridge, 4700', level plant mosaics. Fl. Dec. 6573. Hartz Peak, forming cushions between rocks. Fl. Feb. 6811. Distrib. Summit plateaux; N. Zealand.

1 Cf. J. H. Maiden and Betche. A Census of New South Wales Plants, p. 192. 


\section{Compositae.}

* Olearia persoonioides Benth. Base of Mt Olympus, 2900', under open Eucalyptus. Fl. Jan. 6594. a. Ibid., mountain shrubberies, 3500'. 6594. b. Distrib. Mt Wellington, Middlesex Plains, Lake St Clair.

* Olearia persoonioides Benth. var. alpina Benth. Central plateau, Skeleton Range, $3000^{\prime}$, St Patrick's Plains. Fl., Fr. Jan. 6761. Distrib. (of var.) Mt Wellington, Western Mts.

* Olearia ledifolia Benth. Mt Field E., summit plateau, open shrubberies round Lake Fenton, 3500'. Fl. Nov. 6515. Distrib. Macquarie Harbour, Mts Sorell, Read, La Perouse and Wellington, Field and Dundas.

Celmisia longifolia Cass. Mt Field W., banks of Broad River by Lake Webster, 3500'. Fl. 6554. Distrib. Summit plateaux, where damp; Vict., N.S.W., N. Zealand.

Erigeron pappochromus Labill. W. Coast, Mt Read, summit plateau, 3900, amongst plant mosaics. Fl. Oct. 6436. Mt Field W., summit ridge, $4700^{\prime}$, level plant mosaic. Fl. Dec. 6850. Distrib. Summit plateaux, descending to coast on the west; Vict., N.S.W.

Brachycome scapiformis DC. var. tenuiscapa Benth. Mt Field W., summit ridge, $4700^{\prime}$, tufted in patches and associated with Jevel plant mosaics. Fl. Dec. 6553. Distrib. Arthur's Lakes, Middlesex Plains; Victoria.

*Abrotanella forsterioides Hook. f. Mt Field E., plateau summit, in level plant mosaic cushions. Fl., Fr. Jan. 6579. Distrib. Summit plateaux.

*Helichrysum pumilum Hook. f. W. Coast, Strahan, 300', pebbly places on burnt heath, abundant. Fl. (pink) Oct. 6411. Mt Field W., summit plateau, 3500', open places in dwarf mountain forest. Fl. (white) Dec. 6563. Distrib. Macquarie Harbour, Mts Sorell, Dundas, La Perouse, Adamson's Peak.

*Helichrysum Milligani Hook. f. W. Coast, Mt Read, summit plateau, in level plant mosaic, 4100'. Fl. Oct. 6439. Distrib. Mts Sorell, La Perouse, Adamson's Peak, Surrey Hills.

*Helichrysum Backhousii F. Muell. Mt Field E., summit plateau, shrubberies by Lake Fenton, $3500^{\prime}$, Fl. Oct. 6501. Mt Wellington, summit plateau, $4000^{\prime}$, dense shrubberies. Fl. Dec. 6528. Distrib. Port Arthur, Swanport, Mts Wellington, La Perouse, Sorell, Olympus and Murchison.

*Helichrysum antennarium F. Muell. Mt Wellington, "Spring's zone," 2500-3500', clearings. Fl. Dec. 6531. Dromedary, summit, 3200'. Bud, Nov. 6396. Distrib. Common in uplands.

Helichrysum baccharoides F. Muell. Mt Field E., summit plateau, round Lake Fenton and lining streams above, $3500^{\prime}$. Fl. Nov. 6517. Distrib. Summit plateaux and central plateau; Vict., N.S.W.

*Pterygopappus Lawrencii Hook. f. Mt Field W., summit ridge, 4700', grey-green, in level plant mosaic. Fl. Dec. 6575. Mt Field E., summit plateau, 
$3500^{\prime}$, silver-grey, level plant mosaic cushions. Fl., Fr. Jan. 6580. Distrib. Summit plateaux.

*Raoulia Planchoni Hook. f. Mt Field W., summit plateau, open dwarf forest, 3500', spreading over ground. Fl. Dec. 6564. Mt Olympus, 4000', small couloirs between summit columns. Fl. Jan. 6598. Hartz Mts, Hartz Peak, 4300' , between rocks. Fr. Feb. 6812. Distrib. Mts Wellington, Olympus, Dundas, Ben Lomond.

Raoulia catipes Hook. f. Mt Field W., summit plateau, 3500', in open dwarf mountain forest. Fl. Dec. 6569. Distrib. Western Mts, Look-Out; Victoria.

Senecio pectinatus DC. Mt Field W., summit ridge, $4700^{\prime}$, between rocks. Fl. Dec. 6565. Distrib. Mt Wellington, La Perouse; Vict., N.S.W.

Senecio pectinatus DC. var. pleiocephalus Benth. Mt Field W., summit plateau, open spaces in dwarf forest. Fl. Dec. 6566. Distrib. Western Mts, La Perouse, Sorell and Ironstone; Vict., N.S.W.

*Senecio pectinatus DC. var. ochroleuca Rodw. Mt Olympus, small couloirs between diabase columns of summit plateau. Fl. (cream) Jan. 6592. Hartz Mts, $4000^{\prime}$, summit plateau. Fl. (white) Feb. 6796. Distrib. Summit plateaux.

*Senecio centropappus F. Muell. Mt Wellington, "Spring's zone" round mountain, 2500-3500'. Fl. Dec. 6526. Collin's Bonnet, 3500'. Dec. 6544 (Mrs Linden coll.). Distrib. Mt Wellington, Dromedary. 